\title{
FBI gives in on genetics
}

Washington

THE US Federal Bureau of Investigation (FBI) is responding to criticism that its DNA 'fingerprinting' techniques vastly overstate their reliability by sending researchers on a worldwide hunt for better data on the genetics of ethnic subpopulations.

Introduced in the late $1980 \mathrm{~s}$, DNA fingerprinting has been both hailed as a certain method of identifying a suspect and attacked by critics for producing false matches and mistaken convictions. Recently, that debate has focused on the technique's assumptions regarding population genetics.

One postulate is that three or more genetic markers can identify an individual with near-certainty, with the chances of random matches given as high as one in a trillion in some court cases. In determining the odds, the FBI and private forensic laboratories have usually compared samples with databases of either Caucasian, African-American or Hispanic genetic samples.

But FBI researchers have started to reexamine those assumptions. They are now working with forensic scientists in Europe, Australia and South America to examine DNA databases of ethnic subgroups to see if the world is really as heterogeneous as they have claimed. FBI officials also plan to change their policies so that DNA samples are compared, whenever possible, with profiles obtained from nearby regions rather than the usual large race-based pools for the population at large. According to the newsletter Biotechnology Newswatch, FBI director William Session informed Congress last month that the agency would in the future use samples from more than 50 US geographic areas.

John Hicks, assistant director of the FBI's laboratory division, says that FBI staff scientists will travel to Denmark, Germany, Italy, France and Spain to collect data from forensics DNA laboratories in those countries. Cellmark Diagnostics, a UK-based forensic laboratory, will collect data from other countries, including aboriginal populations in Australia. A typical database of this sort contains DNA fingerprints of between 200 and 300 individuals. Although the FBI hopes to obtain some data from Indian populations in South America, Hicks says, Black populations will not be included in the survey because comparable data is not available.

The FBI's measure is in part a response to the criticism of two population geneticists - Richard Lewontin of Harvard University and Daniel Hartl of the Washington University School of Medicine in St Louis - who argued last December in Science $(254,1745 ; 1991)$ that the FBI's methods of determining chances of coincidental matches may overstate the effectiveness of DNA fingerprinting by orders of magnitude. The fact that many ethnic subgroups are heavily concentrated in certain parts of the United States, Lewontin and Hartl claim, could make the chance of finding a given genetic combination much more likely among those groups. Certain genetic combinations may be more common in Italian neighbourhoods, for example, than in the Caucasian population at large, they say.

Lewontin and Hartl proposed that researchers should study DNA samples from 10 to 15 ethnic groups in Europe to determine just how often certain genetic markers show up in ethnic populations that are relatively homogeneous. If the markers turn out to be relatively common in these ethnic groups, they argue, then forensic researchers should expect clusters of the groups in the United States also to show genetic similarity. That would increase the odds against a coincidental match of DNA samples among these groups.

The FBI says that its assumptions are "reasonable and conservative estimates" that compensate for the possibility of ethnic clustering. But agency officials have nevertheless decided to do much of what Lewontin and Hartl recommended.

When examining the new data, Hicks says, "we want to see if there is any great divergence from the kind of distribution of [DNA] alleles we see in the United States. We've assumed that there isn't."

In a 24 January letter to Representative Don Edwards (Democrat, California), chairman of the House Judiciary Committee's subcommittee on civil and constitutional rights, Hicks described the changes and said that the agency hopes to have the European data collected and analysed by this summer. Edwards plans to hold a hearing on the issue later this year, although no date has been set.

Hartl, although agreeing that the new FBI studies are the type he and Lewontin had called for, says that they are still too "sketchy" to provide conclusive proof about the need to use ethnic subpopulation databases in DNA fingerprinting cases. He points out that incompatible laboratory standards in the various countries could make valid comparisons impossible.

Next month the National Research Council of the National Academy of Science is expected to release a long-awaited report on DNA fingerprinting that will include a chapter on the increasingly controversial population genetics issues. But academy officials say that the report could be delayed because, like nearly everything else in this field, it has become embroiled in politics.

Christopher Anderson

\section{Funding scheme dies}

\section{Sydney}

THE Australian government has backed away from a plan to force pension funds to pour large sums into the commercialization of research after receiving strong criticism from academic and industrial groups.

The critics, in two recent reports, have cited poor results from previous government attempts to encourage venture capital and the lacklustre record of existing Australian industry in commercializing research. Instead of simply boosting the supply of money available for investment, the academic panel suggested, the government should pursue an industrial policy that encourages competition and reduces tariff protection as well as stimulating cooperative efforts by high-technology companies in selected fields.

A top-level task force of businessmen and scientists started the current debate in December with a report to Ross Free, the government's science minister, recommending that pension funds be encouraged to invest one per cent of their assets in venture and development capital projects. That contribution would be mandatory for funds with a significant level of overseas investments. Building upon the government's decision to set up a universal pension fund to be administered by the private sector, the one per cent requirement would eventually make available hundreds of millions of dollars for research and hopefully invigorate the country's sagging economy.

That idea was immediately criticized, however, by an independent government body, the Industry Commission. The commission issued a report concluding that an earlier government attempts to stimulate the supply of venture capital through special tax breaks had failed, with the money either being lost or yielding disappointing returns.

Last month, a report by the Centre for Technology \& Social Change at the University of Wollongong said that the task force has concentrated too much on increasing the supply of research and venture capital. They called the government's proposal an example of "uphill string pushing".

Instead, the report said, the government should try to improve industrial demand for research by encouraging the formation of industry clusters in close geographic proximity.

Earlier this month the Industry Commission issued a second report that further questioned the government's efforts. The report said that a plan to encourage government departments to buy local, hightechnology projects had been a waste of money. Some A\$25 million spent by the programme in four years, it said, had gone to projects that would have gone ahead anyway.

Mark Lawson 